IN MEMORIAM

\title{
Margarita Rosa Groot Sáenz
}

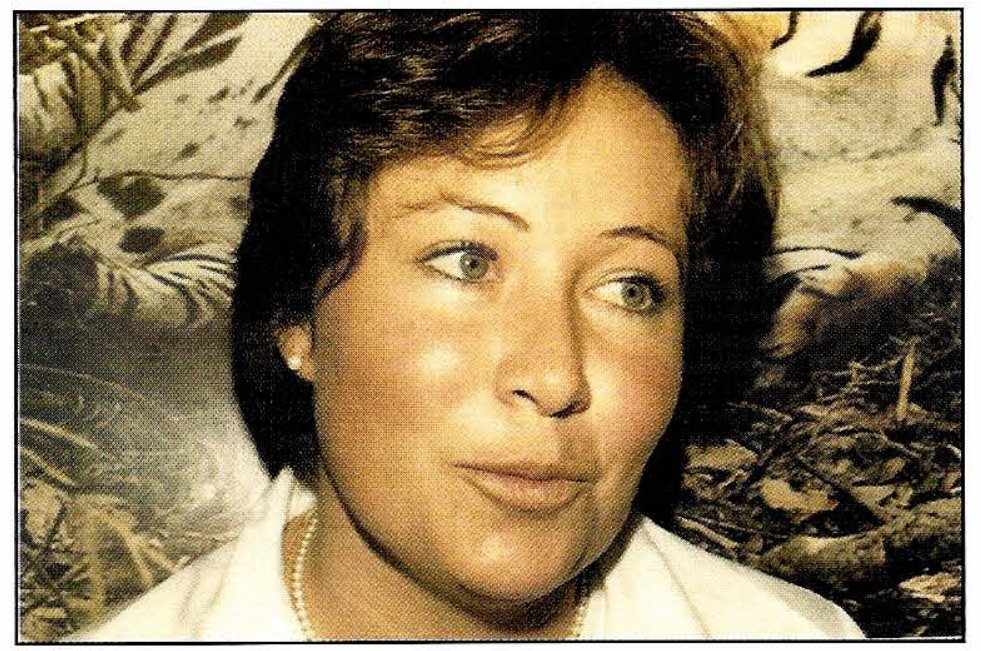

El pasado 28 de enero falleció la doctora Margarita Rosa Groot Sáenz después de dar alegría a sus amigos del Instituto Nacional de Salud durante las últimas dos décadas. Como canciller, la doctora Groot dirigía las relaciones interinstitucionales del Instituto con acierto y señorío, y fue una de sus últimas responsabilidades la de colaborar en la organización del XV Congreso Internacional de Medicina Tropical y Malaria, que recientemente se llevó a cabo en Cartagena con rotundo éxito.

Su eficiencia y consagración, unidos a sus dotes humanas de compañerismo y generosidad, la distinguieron siempre en su brillante carrera profesional. Estuvo vinculada al Instituto inicialmente con el Grupo de Investigación en Malaria y, luego, como directora de la Oficina de Capacitación Humana y Bienestar Social. Graduada de microbióloga en la Universidad de los Andes en 1975 complementó sus estudios de postgrado en la Universidad de Rutgers en los
Estados Unidos y realizó cursos de profundización en Alemania y Austria. Profesional seria y responsable, se distinguía por su exigencia consigo misma y por su rigor en el trabajo, sin que estos rasgos significaran severidad de carácter. Por el contrario, su jovialidad y desparpajo alegraban a quienes la rodeaban por su buen humor y por su contagioso entusiasmo.

Desde su infancia sobrellevó la diabetes que padecía con una fuerza, discreción y energía tales, que nadie adivinaba su terrible carga. Nunca se dejó derrotar por esa adversidad permanente ni permitió que ésta quebrara su naturaleza alegre.

El Instituto Nacional de Salud lamenta con sinceridad su partida porque nos priva de su compañía y, al mismo tiempo, extiende sus sentidas condolencias a toda su familia, en especial a su padre, el doctor Hernando Groot Liévano, ex Director del Instituto y muy distinguido profesor, así como a su señora madre y a sus hermanos. 